\title{
Commentary
}

\section{The Modern Project: A Research Hypothesis}

\author{
Paola Viganò ${ }^{1,2}$ \\ ${ }^{1}$ Lab-U, École Polytechnique Fédérale de Lausanne, 1015 Lausanne, Switzerland; E-Mail: paola.vigano@epfl.ch \\ 2 Dipartimento di Culture del Progetto, University IUAV di Venezia, 30135 Venice, Italy
}

Submitted: 24 September 2019 | Accepted: 24 September 2019 | Published: 30 September 2019

\begin{abstract}
The project of the industrial modern city comprises many heterogeneous paths and stories, in particular those regarding the CIAM (Congrès Internationaux d'Architecture Moderne) Functional City. They all come together in a discourse that links the architectural form to positive urban and social transformations. Such a discourse was interpreted from two different perspectives: The first hypothesized the need for political change starting from the collectivization of land ownership as stressed in the declaration of CIAM at La Sarraz in 1928, whereas the second theorised the capacity of new architecture to improve living conditions irrespective of the political context as supported by Le Corbusier. Starting from these premises, the present commentary proposes a fresh perspective on the functional city project, where the research on the minimization of effort contributed to a different definition of work from the Marxist one and in the modern sense. Therefore, the design and the space of the Existenzminimum blatantly contributes to the construction of a new routine, inspired by minimum effort, with the creation of a new effort-relaxation-rest rhythm and repetition.
\end{abstract}

\section{Keywords}

economic efficiency; Existenzminimum; minimum working effort; Siedlungen; Trabantenprinzip; Ville Contemporaine; Ville Radieuse

\section{Issue}

This commentary is part of the issue "Housing Builds Cities", edited by Luca Ortelli (École Polytechnique Fédérale de Lausanne, Switzerland), Chiara Monterumisi (École Polytechnique Fédérale de Lausanne, Switzerland) and Alessandro Porotto (École Polytechnique Fédérale de Lausanne, Switzerland).

(C) 2019 by the author; licensee Cogitatio (Lisbon, Portugal). This article is licensed under a Creative Commons Attribution 4.0 International License (CC BY).

\section{Experiments: Three Moves}

In the early decades of the 20th century, in the Netherlands, Vienna and Frankfurt, districts and parts of the city were created that would take on an exemplary role in the European debate. According to Carlo Aymonino (1965), the urgency of the solution to the housing problem, established among other things by studies on poverty and sanitation, shifted the topic of urban design from the city as a whole to some of its parts and to specific housing themes. The city expanded through the addition of discreet elements, becoming a place of discontinuity, separation, heterogeneity and estrangement (Foucault, 1984; Secchi, 2000, 2005).

In a fitting reading of the progressive opening up of the block in the 20th century Panerai, Castex, Depaule and Samuels (2004) distinguished three main moves. The first move-explored in south Amsterdam by Hendrik Petrus Berlage between 1901-1905 (see Figure 1) and 1914-1917, and in Vienna by Karl Ehn in the Kark Marx Hof 1100 metres long, 1382 apartments-concerns the expansion of the block and the search for repeatable methods of collective living. The Amsterdam experience is one of the references used by CIAM as an example of the administration and architects working together to improve living conditions.

The second move refers to the opening up of the block. Between 1925 and 1926 Ernst May developed a regulatory plan framework for Frankfurt based on Trabantenprinzip, development for satellite towns influenced by Unwin and Karl Scheffler's (1913) text, Die Architektur der Groszstadt. May had already used it in a competition for the Wroclaw plan of 1921, accompanied by the motto "satellite". 


\section{COGITATIO}

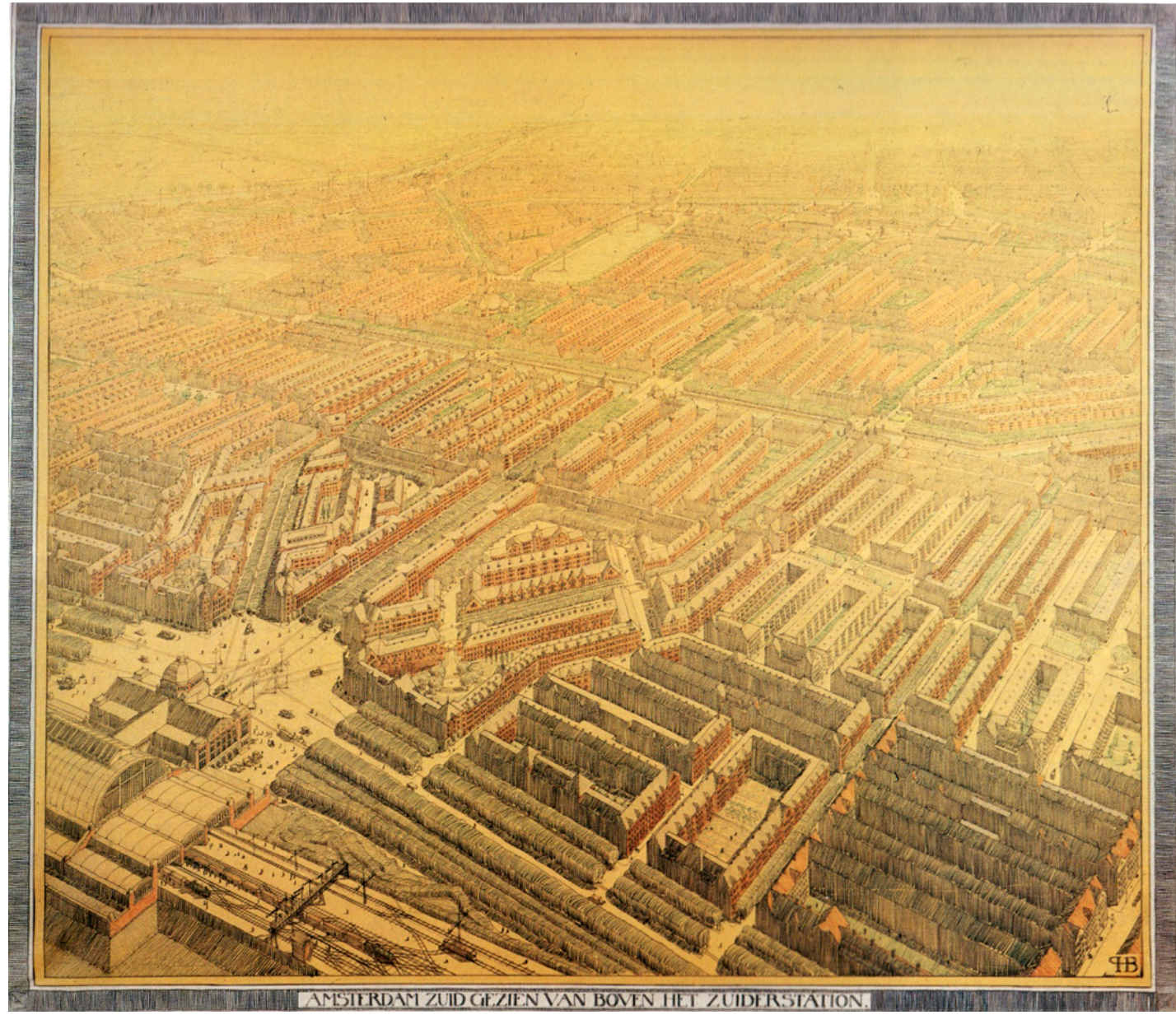

Figure 1. H. P. Berlage, aerial view of the project for south Amsterdam, 1915. Source: Gemeente Amsterdam Stadsarchief (n.d.).

The principle of "satellite towns" was explored (under the influence of Unwin) in the districts of Frankfurt, where Siedlungen are proposed as alternative facts to the nineteenth-century city. We can make the hypothesis that the collection of satellite towns should have been connected by a network of roads and green corridors similar to the one that had already appeared, a few years earlier, in Eliel Saarinen's constructs for Greater Helsinki. May's framework can still be recognized in an image of present-day Frankfurt: among the "satellites" that Scheffler accepted "as the only positive and noncontradictory solution to the questions that the city asks itself" (Grassi, 1975, p. 18), large areas of free space create new continuities in the city. The relationship between satellites and open space is not only functional and ecological: it defines new spatial and architectural characteristics. Giorgio Grassi gave a shrewd interpretation of them that links designs such as that of the Nidda valley, Niddatal (see Figure 2), to a reflection on the role of open space in the construction of a city's architecture. Again, linking Trabantenprinzip to an idea of embellissement, rather than modern functionalist thinking, Grassi on the one hand lost sight of an important relationship, and on the other established and clearly con- firmed the architectural unity between built complexes and open space:

From an architectural perspective, in the classical city, the main function of these green areas related to the buildings, villas or palaces they belonged to, the monuments to which they were related, was to be an inseparable part of their architecture. (Grassi, 1975, p. 29)

For this reason, starting with the Siedlungen project along the river, Grassi reconstructed the fragments of a genealogy that links the building of neighbourhoods along a stretch of open space for the purpose of interrupting the continuity of the urban fabric, to the example of the large villas of the past or the complex of gardens of the Belvedere and Schwarzenberg palaces in Vienna (Grassi, 1975, pp. 29-30).

Frankfurt's Siedlungen still maintain a relationship with the road even if it is not traditional, for example in the Westhausen where the principle of Zeilenbau used for military camps offers the simplicity and repeatability required by industrial production methods. The "Frankfurt kitchen", social services, roof gardens and the 


\section{COGITATIO}

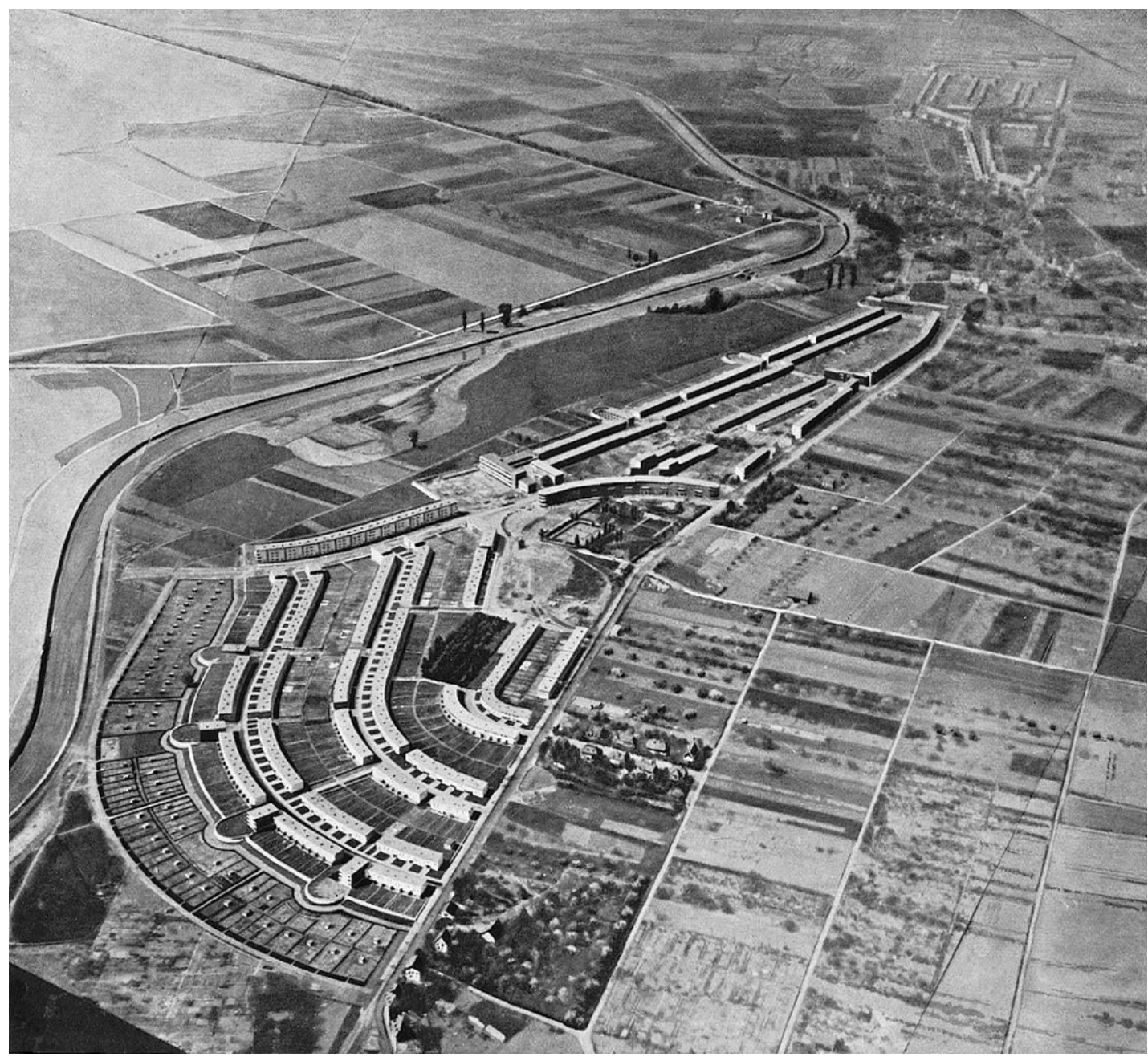

Figure 2. Aerial view of the Nidda valley with the Siedlung Römerstadt in foreground and the Siedlung Praunheim in background. Source: Das neue Frankfurt (1930).

parks designed by Leberecht Migge: the intention was to demonstrate the use of the assembly chain for "socialdemocratic" purposes. The choice to build almost exclusively low, single-family row houses with gardens, the seriality of many installed systems, rigorously anchored to the solar thermal axis and the construction of sequences, divided into public space and private space in which the role of open space turns out to be fundamental, define their main characteristics. Before the imperious choice of "high-rise buildings" established at the 3rd CIAM "Rational Buildings' Methods", specifically in the session "Low-, Medium-, High-Rise Buildings", held in 1930 in Brussels, Frankfurt's Siedlungen represented a sophisticated reflection on the different gradations of space which went from private and individual to public and collective.

The third move stemmed from the idea of a new type of space, definitively and radically different from the previous city: the Ville Radieuse by Le Corbusier which was proposed as "modern" and "revolutionary". In 1930, a competition was announced for a decentralized socialist Garden City for 100,000 people on a site of 15,000 hectares situated 37 kilometres from Moscow, understood as a city of loisir for workers who would have rested on their weekly day off (a vast proletarian model clinic). As is known, strong opposition arose between urbanists (supporters of collective settlements of limited size and shared services) and disurbanists (who propose linear settlements scattered along the transport lines of individual isolated homes; see Figure 3). After the competition, Le Corbusier was asked for his opinion. He lashed out against disurbanists claiming that density is the only guarantee of an economic, social and cultural life (élites inhabit the big city): Starting with his design for the Ville Contemporaine from 1922, Le Corbusier proposed a high-density core and living spaces in green areas. The Russians, interested in his criticisms, presented him with a long questionnaire on the future of Moscow. His Réponse à Moscou, from 8 June 1930, comprised of 66 pages and 21 drawings, was the first formulation of what would become the Ville Radieuse (the Radiant City).

\section{Space and Society: Two Approaches}

Speaking about the modern city, the city that formed starting from the Renaissance, but more specifically the 

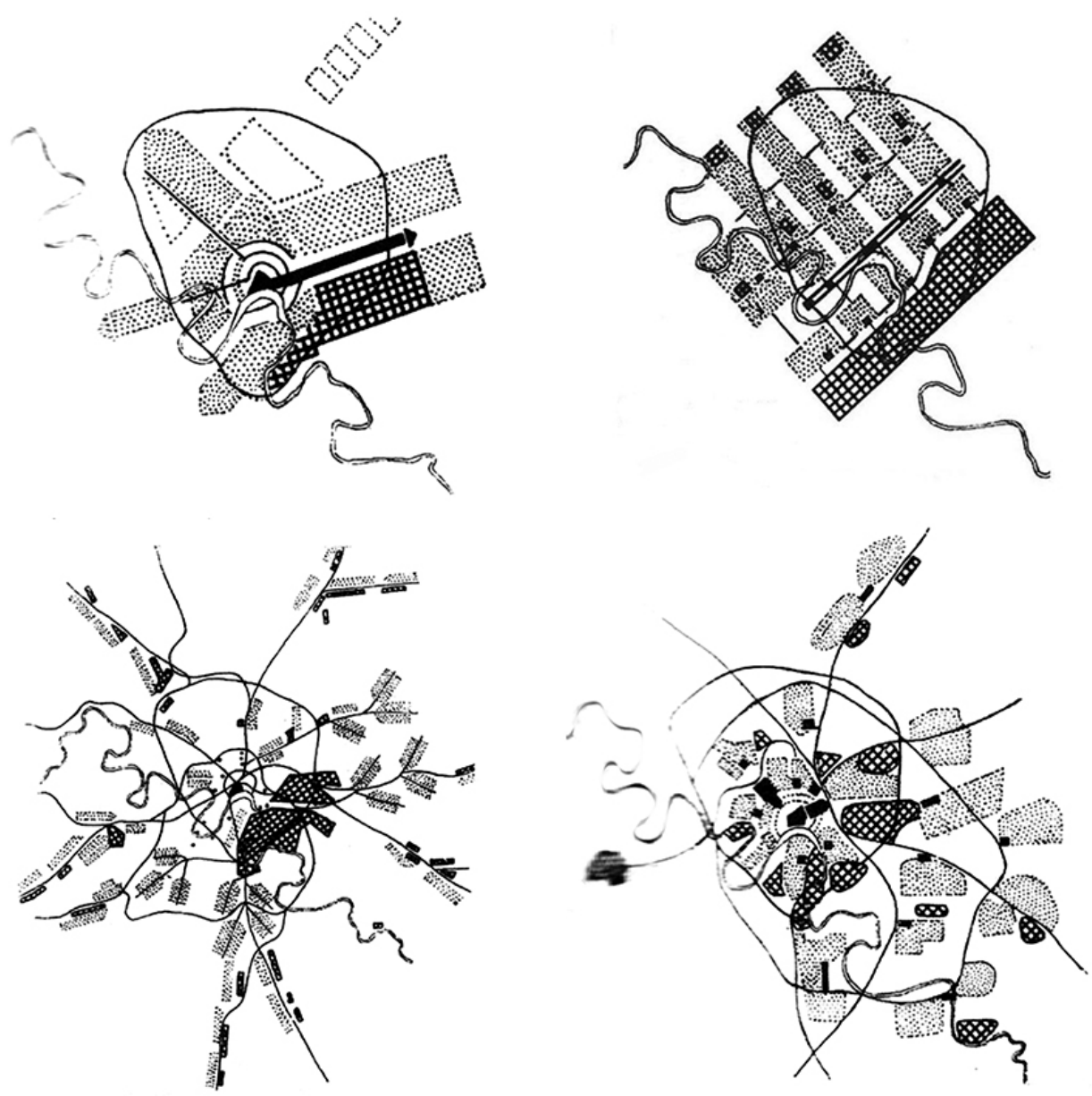

Figure 3. A selection of entries for the Moscow Green City competition. From left to right: brigade of Kratuk (urbanists), WOPRA brigade (urbanists), Hannes Meyer (disurbanists) and Ernst May (disurbanists). Source: Cohen, de Michelis and Tafuri (1930, pp. 143-145).

industrial modern city and, even more specifically, the city of the Modern Movement, is not easy. There are many heterogeneous paths and stories regarding it and concerning the Functional City in particular; they all come together to form a "discourse" according to the Foucault conception (Foucault, 1971; Mumford, 2000) that links the architectural form to positive urban and social transformation.

The discourse established a relationship between the form of architecture and the form of society which the Modern Movement, heir of the nineteenth-century reformist tradition and vanguard of the reflection on welfare developed between the two wars, and above all after the Second World War, interpreted taking two different approaches. The first, which hypothesized the need for political change starting from the collectivization of land ownership, was supported, for example, by the ABC group, formed in 1924 in Basel, and by Mart Stam. Architecture can change the world, as long as the world changes; architecture gives shape to change that has occurred, it is a form of its representation. Kenneth Frampton, in the preface to Eric Mumford's book The CIAM Discourse on Urbanism, 1928-1960 (Frampton,
2000), recalls the declaration of CIAM at La Sarraz in 1928 which remarked on both the link between architecture and the general economic system and the need for a collective land use policy:

The chaotic division of land, resulting from sale, speculations, inheritances, must be abolished by a collective and methodical land policy. This redistribution of land, the indispensable preliminary basis for any town planning, must include the just division between the owners and the community of the unearned increment resulting from works of joint interest. (Conrads, 1970, p. 111)

The second approach, which theorises the capacity of new architecture to improve living conditions irrespective of the political context, was obviously supported by Le Corbusier. Unlike the extreme left wing of the CIAM, throughout the 1920s Le Corbusier sought to apply the lesson of Taylor and Ford to the city and to architecture. Like Ford, Le Corbusier claimed that, since the code of mass production was neutral, it should have been possible to apply it in different regimes and types 
of government. The physical design, more than political actions, would have brought a real improvement to living conditions in an industrial city: "Architecture or revolution", wrote Le Corbusier (1923/1946) in Vers Une Architecture. The research on Existenzminimum, presented at the second CIAM held in Frankfurt in 1929, concerned the search for a biological and not economic minimum and the development of new ways of living together, the hypotheses of which compared even radical ideas of shared spaces.

Was it an overestimation of the role of architecture and its design in society; a loss of sense of proportions, or an attitude of profound cynicism?

\section{A Research Hypothesis}

The hypothesis I put forward is that it was something different, and that Le Corbusier's attitude, like that of others committed to the same research programme, was rather guided by in-depth research on the minimization of effort in an attempt to contribute to a different definition of work from the Marxist one and in the modern sense, as the conquest of a new freedom: Being modern meant conquering a new form of freedom, being free, not so much from work, but from the effort of work. From the etymological point of view, "labour" and "work" contain two traditional characteristics of work: on the one hand occupation which brings suffering and fatigue (in French as well labeur is "charge" and travail derives from the Latin tripalium, an instrument of torture with three stakes); and on the other creation, implementation, not necessarily in opposition to leisure time, loisir.

Conquering a new form of freedom from the effort of work was a research topic, and not a generic positive intention, that gave rise to much of the conviction that architecture is capable of improving the world. In other words, social and political reformism through architecture acts at the level of great detail in which the different bodies enter into relationships and collide; through resistance from and to a specific type of space, the bodies are educated in the modern sense. On the other hand, the La Sarraz declaration also states: "The idea of 'economic efficiency' does not imply production furnishing maximum commercial profit, but production demanding a minimum working effort" (Conrads, 1970, p. 109). The reference to Taylorism is clear, but perhaps a broader interpretation of the terms "economic efficiency" or "minimum working effort" is necessary, capable of revealing the freedom that derives from research on the minimisation of effort and the consequences for spatial relationships between humans and objects.

In 1947, Rudolf Laban dedicated a text to the notion of effort. Laban breaks effort down into four components: space (direct/indirect), weight (strong/light), time (sudden/sustained), flow (bound/free). In Modern Educational Dance, which appeared in 1948 but accounts for the research carried out before the Great War (Laban's dance notation was published in 1928), he com- bines research on the new forms of dance (modern or free) with the application of these studies on movement to industry:

Starting with this wide range of physical efforts, Laban revisited his notions of rhythm and dynamics in expressive dance to adapt them to an economic use of rhythm, aiming to obtain the best possible performance.... Unlike experts in the study of time and movement, Laban refused to use a technique based on the stopwatch to accelerate workers' movements. (Laban, 1948, pp. 145-146)

The efficiency of the effort is not, for Laban nor for the CIAM, the product of faster movements, rather it consists of an improved and more efficient relationship between the movements, in the equilibrium between effort, relaxation and rest which brings novelty and new awareness to the actions carried out in everyday life.

The Frankfurt kitchen was designed by Margarete Schütte-Lihotzky in 1927 and was inspired by train kitchens, Laban's notation was published in 1928 and a photo of Laban's free dances in Ascona dates to 1914 (see Figure 4). Research by Margarete Schütte-Lihotzky continued and backed up previous research in the US by the Beecher sisters, in particular Catherine, in the second half of the 1800s, which led to the elimination of the central table, the introduction of the continuous worktop and ultimately to the reduction of a space still designed for hired help; by Christine Frederick, who taught domestic science and was translated and published in 1924 by Bruno Taut, or Lilian Gilbreth, engineer, who in the 1920s, initially with her husband, used diagrams and plastic to study in Taylorist terms the reorganisation of movement in the kitchen space. Paulette Bernège, founder and president of the Ligue d'Organisation Menagère in France, was invited to the CIAM of Frankfurt in 1929 dedicated to Existenzminimum (Clarisse, 2004; Hayden, 1981; Eleb \& Debarre, 1995). The reduction and simplification of a housewife's movements in the kitchen, like the simplification and reduction of the pathways inside housing in Alexander Klein's famous plans, translate in the city into a simplification and reduction of the urban spatial complexity of the past through the separation of flows, the elimination of obstacles and possible conflicts, and the transparency of the space. The minimization of routes, in diagrams by disurbanists, upsets the organisation of the living space (Baburov, Djumenton, \& Gutnov, 1968, p. 135).

Beyond the minimization of effort, the effortrelaxation-rest equilibrium is guaranteed by the introduction of the loisir space within the city: in profoundly different ways from the nineteenth-century and early twentieth-century city in which the role of the public park was to counterbalance factories and pollution, the large green carpet equipped for sport, games, treatment and relaxation of the body and spirit in the modern city emphasises, in its continuity, the complementarity, in the Functional City, between effort and relaxation. 


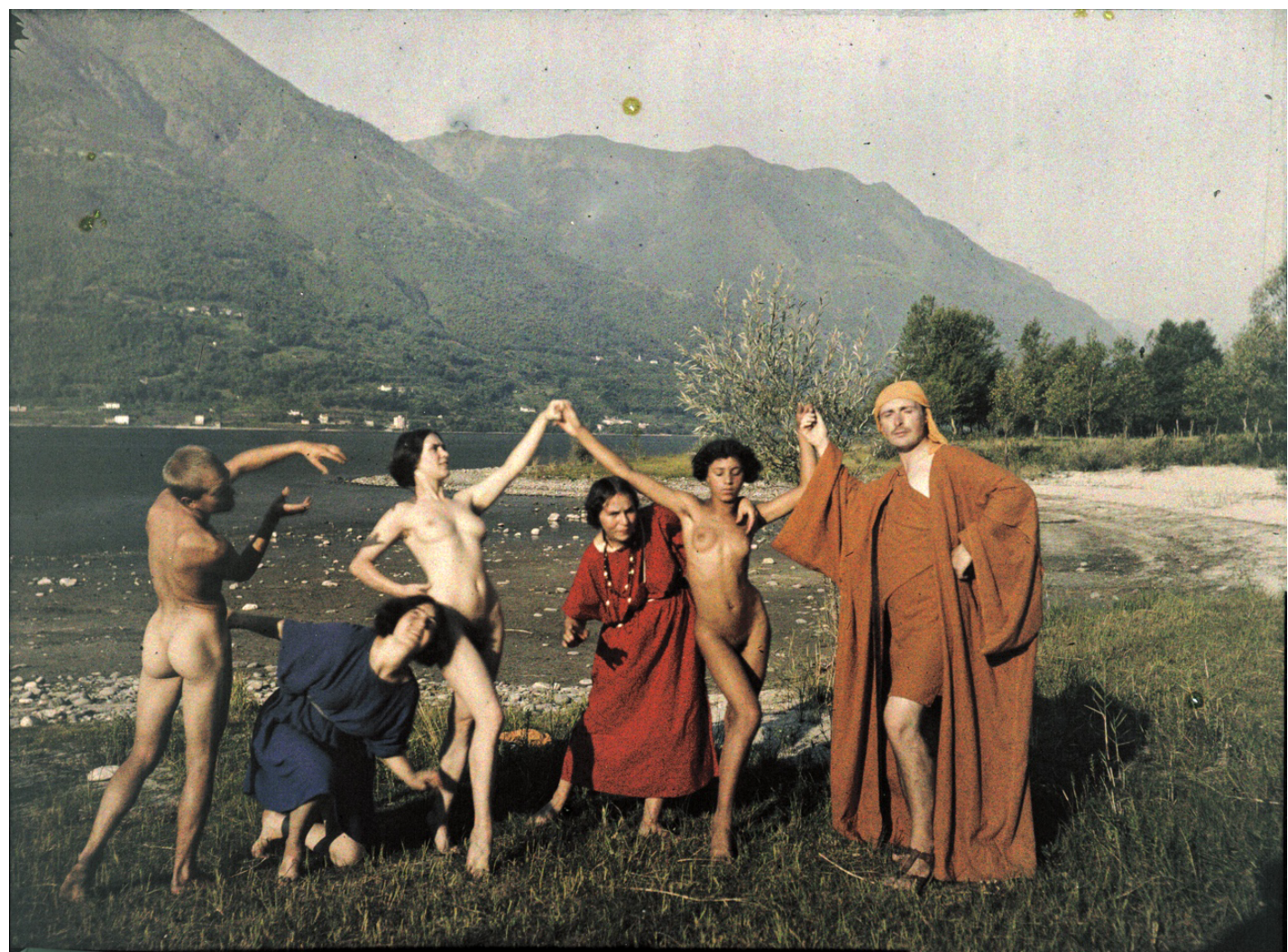

Figure 4. Rudolf Laban and the performance of free dances at the Monte Verità in Ascona (Switzerland), 1914. Source: Johann Adam Meisenbach (1914).

The city of the Modern Movement blatantly contributes to the construction of a new routine, inspired by minimum effort, the creation of a new effort-relaxationrest rhythm and repetition (Eugenides, 2002; Sennet, 1998): "Floating somewhere between socialism and social welfare", as Aldo van Eyck (1981, p. 17) said of the CIAM.

\section{Acknowledgments}

This commentary expands on the contribution "1928, La Sarraz" in Racines modernes de la ville contemporaine. Distances et formes de résilience (Modern Roots of the Contemporary City. Distances and Resilient Forms; MetisPresses, 2019). I thank Rebecca Milner for the translation of the commentary into English.

\section{Conflict of Interests}

The author declares no conflict of interests.

\section{References}

Aymonino, C. (1965). Le origini della città moderna [The origins of the modern city]. Padua: Marsilio.

Baburov, A., Djumenton, G., \& Gutnov, A. (1968). Idee per la città comunista [Ideas for the communist city]. Milan: II Saggiatore.

Clarisse, C. (2004). Cuisine, recettes d'architecture
[Kitchen, recipes of architecture]. Besançon: Les Editions de l'imprimeur.

Cohen, J. L., de Michelis, M., \& Tafuri, M. (1979). URSS 1917-1918: La ville, l'architecture/URSS 1917-1918: La città, l'architettura [URSS 1917-1918: City, architecture]. Paris, Rome: L'Equerre and Officina.

Conrads, U. (Ed.). (1970). Programs and manifestoes on 20th-century architecture. Cambridge, MA: MIT Press.

Das neue Frankfurt. (1930). Air photograph of the Nidda Valley with the colonies of Römerstadt and Praunheim. Das neue Frankfurt: Internationale Monatsschrift für die Probleme kultureller Neugestaltung, 1930(4/5). Retrieved from https://digi.ub.uniheidelberg.de/diglit/neue_frankfurt1930/0147/ image

Eleb, M., \& Debarre, A. (1995). L'invention de I'habitation moderne, Paris 1880-1914 [The invention of the modern housing, Paris 1880-1914]. Brussels: AAM Editions.

Eugenides, J. (2002). Middlesex. New York, NY: Farrar Straus and Giroux.

Foucault, M. (1971). L'ordre du discours [The order of discourse]. Paris: Gallimard.

Foucault, M. (1984). "Des espaces autres" [Of other spaces]. Architecture, Mouvement, Continuité, 5, 46-49.

Frampton, K. (2000). Foreword. In E. Mumford (Ed.), The CIAM discourse on urbanism, 1928-1960 (pp. xi-xv). 
Cambridge, MA: MIT Press.

Gemeente Amsterdam Stadsarchief. (n.d.). Amsterdam South seen from above the Zuiderstation. Beeldbank Amsterdam. Retrieved from https://beeldbank. amsterdam.nl/beeldbank/weergave/record/? $\mathrm{id}=$ ANWS00298000001

Grassi, G. (1975). Das Neue Frankfurt e l'architettura della nuova Francoforte [Das Neue Frankfurt and the architecture of the new Frankfurt]. Bari: Dedalo libri.

Hayden, D. (1981). The grand domestic revolution. Cambridge, MA: MIT Press.

Johann Adam Meisenbach. (1914). Tanzende am Lago Maggiore bei Ascona [Dancers at lake Maggiore in Ascona] [Autochrome]. Estate Suzanne Perrottet Photographs (Persistent identifier No. 78939). Kunsthaus Zürich. Retrieved from https://digital.kunsthaus.ch/ viewer/!metadata/78939/9/-/

Laban, R. (1948). Modern educational dance. London: Macdonald \& Evans.

Le Corbusier. (1946). Towards a new architecture. Lon- don: Architectural Press. (Original work published 1923)

Mumford, E. (2000). The CIAM discourse on urbanism, 1928-1960. Cambridge, MA: MIT Press.

Panerai, P., Castex, J., Depaule, C., \& Samuels, I. (2004). Urban forms: The death and life of the urban block. Architectural Press. Oxford. Paris: Bordas.

Scheffler, K. (1913). Die Architektur der Groszstadt [The architecture of the metropolis]. Berlin: Bruno Cassirer.

Secchi, B. (2000). Prima lezione di urbanistica [First lecture of urbanism]. Bari: Laterza.

Secchi, B. (2005). La città del XX secolo [The city of the 20th century]. Bari: Laterza.

Sennet, R. (1998). The corrosion of character. The personal consequences of work in the new capitalism. New York, NY: W. W. Norton \& Company.

van Eyck, A. (1981). What is and isn't architecture: À propos of rats, posts and other pests. Lotus, 28, 15-21.

\section{About the Author}

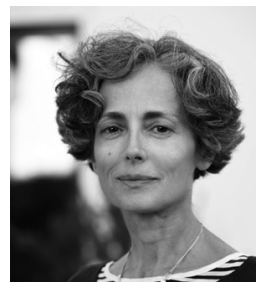

Paola Viganò is Professor of Urban Theory and Urban Design at the EPFL (where she directs the Lab-U and Habitat Research Center) and at IUAV, Venice. In 1990, together with Bernardo Secchi, she founded Studio and carried out projects in Europe up until 2014. She established StudioPaolaViganò in 2015. She received the Grand Prix de I'Urbanisme in 2013, the Ultima Architectuur Prize (Flemish Culture Award for Architecture) in 2017, and was awarded the "career" Golden Medal of Architecture by the Milan Triennale in 2018. She was Doctor Honoris Causa at the Université Catholique Louvain in 2016. Her main recent publications include: The Territory of Urbanism (Routledge EPFL Press, 2016), The Horizontal Metropolis. Between Urbanism and Urbanization (Springer, 2018; co-editor with Martina Barcelloni Corte and Chiara Cavalieri) and The Horizontal Metropolis. A Radical Project (Park, forthcoming; co-editor with Chiara Cavalieri). 